\title{
Isolation and characterization of some flavonoids from the leaf of Tapinanthus globiferus growing on Vitex doniana
}

\author{
H. Abubakar ${ }^{1}, *$, \\ A. M. Musa ${ }^{2}$, \\ V. Mzozoyana ${ }^{4}$ and A. J. Yusuf ${ }^{3}$ \\ M. I. Abdullahi ${ }^{3}$,
}

${ }^{1}$ Sokoto State University. Department of Chemistry. Sokoto. Nigeria. Email: hassan.abubakar@ssu.edu.ng.

${ }^{2}$ Ahmadu Bello University. Department of Pharmaceutical and Medicinal Chemistry. Zaria, Nigeria.

${ }^{3}$ Usmanu Danfodiyo University. Department of Pharmaceutical and Medicinal Chemistry. Sokoto. Nigeria.

${ }^{4}$ University of KwaZulu-Natal. School of Chemistry and Physics. Westville. Durban. South Africa.

\begin{abstract}
Tapinanthus globiferus (A. Rich) Tiegh (Loranthacae) is a semi-parasitic plant growing on several plant species such as Vitex doniana. it is used in ethno-medicine for the treatment of fungal infection, itching, hypertension, ulcers, epilepsy, diabetes and cancer. The aim of this study was to isolate bioactive compound(s) from the leaf of T. globiferus. The powdered plant material was extracted with $90 \%$ methanol using maceration method and the resulting crude methanol leaf extract was partitioned into $n$-hexane, chloroform, ethylacetate and $n$-butanol fractions. The ethylacetate fraction was chromatographed on a silica gel and sephadex LH-20 column which led to the isolation of two flavonoids, and the identity of the compounds was determined on the basis of chemical test and NMR analysis. Based on the 1D and 2D NMR data, the compounds were 2-(3'4'-dihydroxyphenyl)-3,5,7-trihydroxy-4Hchromane-4-one (quercetin) and 2-(2,4-dihydroxyphenyl)-5,7dihydroxy-3-(3-methylhexyl)-4H-chromen-4-one. This is the first report of isolation of these compounds from T. globiferus growing on Vitex doniana.
\end{abstract}

Keywords: Tapinanthus globiferus; Leaf; Isolation; NMR.
Received

October 23, 2019

Accepted

December 30, 2020

Released

December 31, 2020

Full Text Article

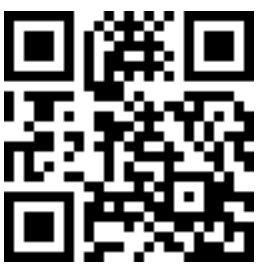

ORCID

(D) $0000-0003-1039-5782$

H. Abubakar

ㄴ) 0000-0001-7985-9157

A. M. Musa

(1) 0000-0002-9049-9057 M. I. Abdullahi

(1) 0000-0002-6679-1541

V. Mzozoyana

() 0000-0002-4557-859X

A. J. Yusuf 


\section{Introduction}

Tapinanthus globiferus (A. Rich) Tiegh belonging to the Loranthaceae Family is a semi-parasite with glabrous pendulous stems up to $1.2 \mathrm{~m}$ long with roots that mostly grows on the branches of a large number of tree species including Vitellaria paradoxa, Kola, Citrus, Combretum, Acacia, Aloe and Terminalia as host trees (Waterberg et al., 1989; Polhill and Wiens, 1998). It is commonly known as mistletoe (English), Kauchi (Hausa), afomo (Yoruba), and Osisi/Okwuma osa (Igbo) in Nigeria. T. globiferus is used in ethnomedicine to treat itching (Burkill, 2000), tumour (Yineger and Yewhalaw, D., 2007) and removal of placenta after parturition (Sher and Alyemeni, 2011). The plant is also used to treat diseases such as hypertension, ulcers, epilepsy, diabetes, weakness of vision and promoting muscular relaxation before delivery (Bassey, 2012). Ogunbolude et al. (2014) reported the identification and quantification of quercetin and some phenolic acids from T. globiferus growing on other host. Biological studies of T. globiferus growing on other hosts have been documented. Antitrypanosomal (Abedo et al., 2013) and anticonvulsant (Abubakar et al., 2016) activities of the plant were also reported. Extensive literature search revealed that there is no report yet on the isolation and characterization of any compound from the plant T. globiferus growing on Vitex doniana.

We report herein, the isolation and characterization of two flavonoids, quercetin and 2-(2,4-dihydroxyphenyl)-5,7-dihydroxy-3-(3-methylhexyl)-4H-chromen-4-one from the leaf $T$. globiferus growing on Vitex doniana.

\section{Materials and methods}

\section{General procedures}

NMR data were recorded on a Bruker AVANCE spectrometer $(600 \mathrm{MHz})$ with residual solvent as internal standard. Melting point was determined on an Electro thermal melting point apparatus. Thin layer chromatography (TLC) was carried out using silica gel $60 \mathrm{GF}_{254}$ pre-coated aluminium sheets by Sigma Aldrich, Germany. Low pressure column and Vacuum liquid chromatography were conducted using LOBA Cheme silica gel (60-200) mesh in a sintered glass funnel while gel filtration chromatography was performed using sephadex LH-20 (Sima, Spruce Street, St. Louis, MO, USA). Spots on TLC plates were visualized by spraying with $10 \% \mathrm{H}_{2} \mathrm{SO}_{4}$ followed by heating at $105{ }^{\circ} \mathrm{C}$ for 10 min.

\section{Plant sample}

Plant sample of T. globiferus growing on Vitex doniana was collected from Dange Shuni Local Government Area of Sokoto State, Nigeria in December 2016. It was identified and authenticated by Namadi Sanusi of the Herbarium Section, Department of Biological Sciences, Ahmadu Bello University Zaria, with a voucher (No. 900107). The plant material was air dried, pulverized, labelled and stored in a polythene bag for further use.

\section{Isolation of compounds}

The powdered leaf of $T$. globiferus $(2.0 \mathrm{~kg}$ ) was exhaustively extracted with $3 \mathrm{~L}$ of $90 \%$ methanol for 6 days. The extract was filtered using Whatman No. 1 filter paper and the filtrate was evaporated to dryness using rotary evaporator at $40{ }^{\circ} \mathrm{C}$ to afford crude methanol leaf extract $(140 \mathrm{~g})$. Some part of the extract $(120 \mathrm{~g})$ was partitioned into $n$-hexane, chloroform, ethylacetate and $n$-butanol fractions. The ethylacetate fraction $(3 \mathrm{~g})$ was subjected to purification using VLC with $n$-hexane: ethylacetate mixtures as solvent systems. Twenty $(20 \mathrm{~mL})$ of a total of 60 collections were made and combined based on their TLC profile to afford four major fractions coded A-D. Fraction D was further purified using a combination of low pressure column and sephadex LH-20 column to afford a 
yellow amorphous substance, $10 \mathrm{mg}$ (Compound 1). A portion of the ethylacetate fraction $(4 \mathrm{~g})$ was chromatographed on a silica gel column with $n$-hexane: ethylacetate mixtures as solvent systems and a total of seventy six collections were made and merged based on their TLC profile to afford seven major fractions coded E1-E7. Repeated gel filtration of fraction E3 led to the isolation of a yellow amorphous substance, $8 \mathrm{mg}$ (Compound 2).

\section{Results}

\section{Spectral data}

Quercetin (1). Yellow amorphous substance; m.p. $315{ }^{\circ} \mathrm{C}-316{ }^{\circ} \mathrm{C} .{ }^{1} \mathrm{H}-\mathrm{NMR}\left(\mathrm{CD}_{3} \mathrm{OD}\right.$, $600 \mathrm{MHz}$ ): $\delta_{H} 7.76\left(1 \mathrm{H}, \mathrm{d}, J=1.38 \mathrm{~Hz}, \mathrm{H}-2^{\prime}\right), 6.92\left(1 \mathrm{H}, \mathrm{d}, J=8.4 \mathrm{~Hz}, \mathrm{H}-5^{\prime}\right), 7.67$ (1H, dd, J=1.7, $8.4 \mathrm{~Hz}, \mathrm{H}-6$ ') 6.42 (1H, d, J=1.56 Hz, H-8), 6.22 (1H, d, J=1.50 Hz, H-6). ${ }^{13} \mathrm{C}-\mathrm{NMR}\left(\mathrm{CD}_{3} \mathrm{OD}\right.$, $600 \mathrm{MHz}$ ): $\delta_{C} 146.7$ (C-2), 135.8 (C-3), 176.0 (C-4), 161.1 (C-5), 97.9 (C-6), 164.2 (C-7), 93.1 (C-8), 156.9 (C-9), 103.1 (C-10), 122.8 (C-1'), 114.6 (C-2'), 144.8 (C-3'), 147.7 (C-4'), 114.9 (C-5'), 120.3 (C-6').

2-(2,4-dihydroxyphenyl)-5,7-dihydroxy-3-(3-methylhexyl)-4H-chromen-4-one (2). Yellow amorphous substance; m.p $245^{\circ} \mathrm{C}-246^{\circ} \mathrm{C} .{ }^{1} \mathrm{H}-\mathrm{NMR}\left(\mathrm{CD}_{3} \mathrm{OD}, 600 \mathrm{MHz}\right): \delta_{H} 7.76(1 \mathrm{H}$, s, H-3'), $6.92\left(1 \mathrm{H}, \mathrm{d}, J=8.5 \mathrm{~Hz}, \mathrm{H}-6^{\prime}\right), 7.67\left(1 \mathrm{H}, \mathrm{d}, J=8.1 \mathrm{~Hz}, \mathrm{H}-5^{\prime}\right), 6.42(1 \mathrm{H}, \mathrm{d}, J=1.5 \mathrm{~Hz}, \mathrm{H}-8)$, $6.21(1 \mathrm{H}, \mathrm{d}, J=1.8 \mathrm{~Hz}, \mathrm{H}-6) .{ }^{13} \mathrm{C}-\mathrm{NMR}\left(\mathrm{CD}_{3} \mathrm{OD}, 600 \mathrm{MHz}\right): \delta_{C} 146.7(\mathrm{C}-2), 100.0(\mathrm{C}-3), 176.0$ (C-4), 161.1 (C-5), 97.9 (C-6), 164.2 (C-7), 93.1 (C-8), 156.9 (C-9), 103.1 (C-10), 122.8 (C-1'), 147.3 (C-2'), 114.4 (C-3'), 144.8 (C-4'), 114.6 (C-5'), 114.8 (C-6'), 35.1 (C-1"), 31.6 (C-2"), 28.9 (C-3"), 25.5 (C-4"), 29.3 (C-5"), 13.0 (C-6"), 22.3 (C-1"').

\section{Discussion}

Compound 1 was obtained as a yellow amorphous substance and it tested positive to shinoda and ferric chloride reagent suggesting the compound to be a flavonoid (Silva et al., 1998). The ${ }^{1} \mathrm{H}-\mathrm{NMR}$ spectrum of compound 1 indicated the presence of $1,2,3$, 5-tetrasubstituted benzene ring A via the meta-coupled protons at $\delta 6.42(1 \mathrm{H}, \mathrm{d}, J=1.50$ $\mathrm{Hz})$ and $\delta 6.21(1 \mathrm{H}, \mathrm{d}, J=1.56 \mathrm{~Hz})$ which were assigned to $\mathrm{H}-6$ and $\mathrm{H}-8$ respectively and 1 , 3, 4-trisubstituted benzene ring B was observed via protons at $\delta 7.76(1 \mathrm{H}, \mathrm{d}, J=1.38 \mathrm{~Hz}$, H-8'), $\delta 7.67\left(1 \mathrm{H}, \mathrm{dd}, J=1.7 \mathrm{~Hz}, 8.4 \mathrm{~Hz}, \mathrm{H}-6^{\prime}\right)$ and $\delta 6.92\left(1 \mathrm{H}, \mathrm{d}, J=8.4 \mathrm{~Hz}, \mathrm{H}-5^{\prime}\right)$. The ${ }^{1} \mathrm{H}-{ }^{1} \mathrm{H}-\mathrm{COSY}$ established the correlation between protons that lie adjacent to each other; the observed correlation between proton at $\delta 6.21$ and $\delta 6.42 \mathrm{ppm}$ and the protons at $\delta 6.92$ and $\delta 7.76 \mathrm{ppm}$ further confirmed the assignment of ring A and B above (Sani et al., 2015).

The ${ }^{13} \mathrm{C}$-NMR and DEPT experiments of compound 1 revealed the presence of 15-carbon atoms (Table 1), seven aromatic carbon signals, seven quaternary oxygenated carbon atoms and a down field signal due to carbonyl carbon resonating at $\delta 176.0$ (C-4). These signals suggests a flavonoid-quercetin nucleus (Mabry et al., 1970). The HSQC spectrum was used to attach various protons to their respective carbon atoms and the connectivity between various fragments was established through HMBC. It established the correlation between proton at $\delta_{H} 6.21(\mathrm{H}-6)$ and the carbons at $\delta c 93.1(\mathrm{C}-8), \delta 103.1$ $(\mathrm{C}-10), \delta 161.1(\mathrm{C}-5), \delta 164(\mathrm{C}-7)$ and proton at $\delta_{H} 6.42(\mathrm{H}-8)$ correlated with the carbons at $\delta 97.9(\mathrm{C}-6), \delta 103.1$ (C-10), $\delta 156.9$ (C-9), $\delta 164.2$ (C-7) further confirming the presence of 1,2,3,5- tetrasubstituted benzene ring A. Long range correlation at observed at $\delta_{H} 6.92$ $\left(\mathrm{H}^{\prime} 5^{\prime}\right)$ and carbons at $\delta 122.8$ (C-1'), $\delta 144.8$ (C-3'), $\delta 147.4$ (C-4') and $\delta 7.67$ and carbons $\delta 114.6$ (C-2'), $\delta 144.7$ (C-3') and $\delta_{H} 7.76$ (H-2') and $\delta 120.3$ (C-6'), $\delta 144.8$ (C-4'), $\delta 146.7$

(C-2) confirmed the presence of 1,3,4'-trisubstituted benzene ring B. Based on the $1 \mathrm{D}$ and 2D NMR data of compound 1 and comparison with the reported literature (Mabry et al., 1970; Sani et al., 2015), the structure of compound 1 was confirmed to be a quercetin (Figure 1). 
Compound 2 was obtained as a yellow amorphous substance and it gave positive result in the test for flavonoid using shinoda test (Silva et al., 1998). The NMR data of compound 2 exhibited similarities with those of compound $1 .{ }^{1} \mathrm{H}-\mathrm{NMR}$ spectrum revealed signals for meta-coupled protons at $\delta_{H} 6.42(1 \mathrm{H}, \mathrm{d}, J=1.5 \mathrm{~Hz}, \mathrm{H}-8)$ and $\delta_{H} 6.21(1 \mathrm{H}, \mathrm{d}, J=1.8$ $\mathrm{Hz}, \mathrm{H}-6)$ typical of a 1, 2, 3, 5-tetrasubtituted benzene ring A and a pair of ortho-coupled protons were observed at $\delta_{H} 6.92\left(1 \mathrm{H}, \mathrm{d}, J=8.5 \mathrm{~Hz}, \mathrm{H}-6^{\prime}\right)$ and $\delta_{H} 7.67\left(1 \mathrm{H}, \mathrm{d}, J=8.1 \mathrm{~Hz}, \mathrm{H}-5^{\prime}\right)$ alongside a singlet at $\delta_{H} 7.76\left(1 \mathrm{H}, \mathrm{s}, \mathrm{H}-3^{\prime}\right)$ which were assigned to 1, 4, 6-trisubstituted benzene ring $\mathrm{B}$, typical of flavonoids ${ }^{12}$. Additional aliphatic signals were observed at $\delta_{H}$ 0.89 (H-6”), 0.93 (H-1”), 1.36 (H-3”), 1.62 (H-2”), 2.05 (H-4”) 1.34 (H-1”) and 2.21 (H-1”) typical of an aliphatic side chain.

${ }^{1} \mathrm{H}-{ }^{-1} \mathrm{H}-\mathrm{COSY}$ experiment was used to further confirmed the assignment of metacoupled protons at $\mathrm{H}-6$ and $\delta \mathrm{H}-8$ and ortho-coupled protons at $\mathrm{H}-6^{\prime}$ ' and $\mathrm{H}-5^{\prime}$ '. Cross peaks correlations observed between protons at H-1" \# H-2", H-3" \# H-2”, H-3" \# H-4”, H-3” \# H-1"' further substantiate the presence of aliphatic side chain as part of the structure.

The ${ }^{13} \mathrm{C}$-NMR (600 MHz, $\mathrm{CD}_{3} \mathrm{OD}$ ) and DEPT experiment of compound 2 revealed the presence of seven aromatic carbon signals, six quaternary oxygenated aromatic carbon atoms and a down field signal due to carbonyl carbon resonating at $\delta 176.0$; the absence of a resonance at $\delta 135.8(\mathrm{C}-3)$ as observed in flavonols and the presence of a signal at $\delta$ 120.3 further suggests a flavone type nucleus (Mabry et al., 1970). Aliphatic resonances at Sc 35.1 (C-1”), 31.6 (C-2”), 29.3 (C-5”), 28.9 (C-3”), 25.5 (C-4”), 22.3 (C-1”), 13.0 (C-6”) further confirmed the presence of aliphatic side chain of flavone type which is consistent with the proton NMR.

The HSQC spectrum established direct correlation between protons and their respective carbons. Aliphatic side chain was further substantiated by the correlations observed between the proton at $\delta_{H} 1.36$ and $\delta c 28.9 \# 1.36$, and $\delta_{H} 1.34$ and 29.3 among others.

The connectivity between various fragments was established through HMBC. It established a long range correlation between the proton at $\delta_{H} 6.21(\mathrm{H}-6)$ with the carbons at $\delta c 93.1$ (C-8), 103.1 (C-10), 161.1 (C-5), 164.2 (C-7) and the proton at $\delta_{H} 6.42$ (C-8) correlated with the carbons at $\delta c 97.9$ (C-6), 103.1 (C-10), 156.9 (C-9), 164.2 (C-7) which confirmed the presence of ring A. Correlation of proton at $\delta 6.92$ (C-6') with carbons at $\delta 122.8$ (C-1'), $\delta 144.8$ (C-4'), $\delta 146.7$ (C-2) and $\delta 147.3$ (C-2') further confirmed the position of hydroxyl groups at position 2' and 4' on ring B in the flavone nucleus (Pratkit, 2010). Proton at $\delta 7.76$ (C-5') correlate with the carbon at $\delta 122.3$ (C-3'). The absence of a downfield signal at $\delta c 135$ and a proton signal at C-3 suggests that, the prenyl chain (aliphatic chain) might be attached to the C-3 of flavone nucleus. Based on the 1D and 2D-NMR data of compound 2, a tentative structure was proposed as 2-(2,4dihydroxyphenyl)-5,7-dihydroxy-3-(3-methylhexyl)-4H-chromen-4-one (Figure 2).
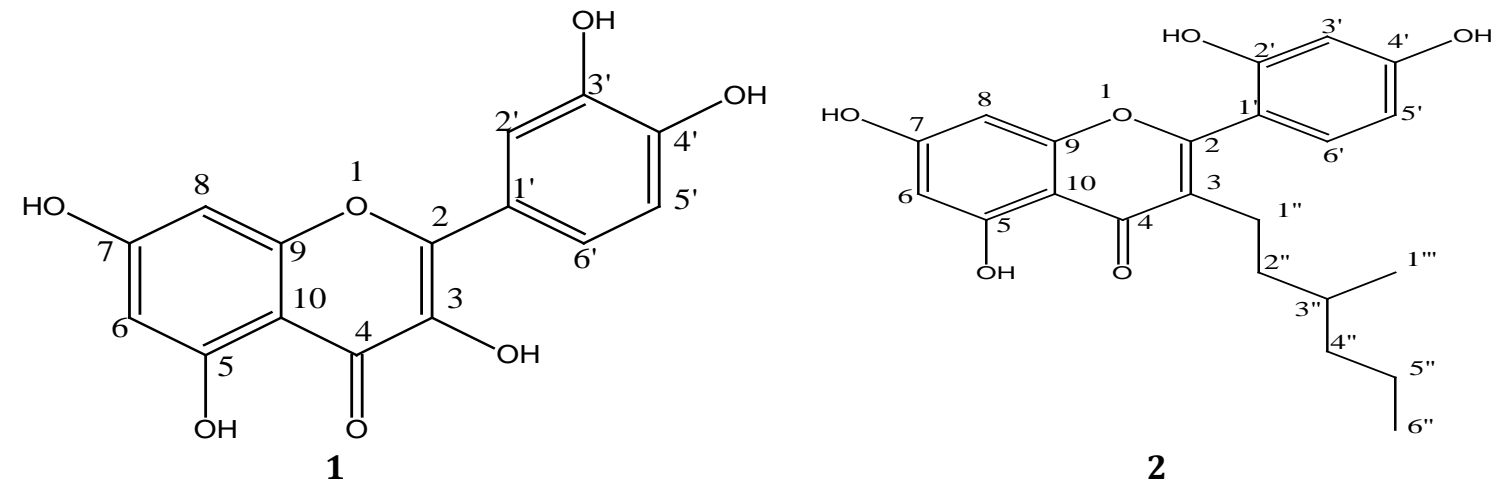

2

Figure 1. Structure of compounds 1 and 2. 
Table 1. Summary of 1D and 2D spectral data of Compound 1 (CD3OD, $600 \mathrm{MHz}$ ).

\begin{tabular}{|c|c|c|c|c|c|}
\hline Position & $\delta^{13} \mathrm{C}$ & $\delta^{1} \mathrm{H}, J(\mathrm{~Hz})$ & DEPT & $\operatorname{cosY}$ & HMBC \\
\hline 2 & 146.7 & & $\mathrm{C}$ & & \\
\hline 3 & 135.8 & & $\mathrm{C}$ & & \\
\hline 4 & 176.0 & & $\mathrm{C}$ & & \\
\hline 5 & 161.1 & & $\mathrm{C}$ & & \\
\hline 6 & 97.9 & $6.21(1 \mathrm{H}, \mathrm{d}, J=1.56)$ & $\mathrm{CH}$ & $\mathrm{H}-8$ & $\mathrm{C}-8,5,7,10$ \\
\hline 7 & 164.2 & & $\mathrm{C}$ & & \\
\hline 8 & 93.1 & $6.42(1 \mathrm{H}, \mathrm{d}, J=1.50)$ & $\mathrm{CH}$ & $\mathrm{H}-6$ & $\mathrm{C}-6,7,9,10$ \\
\hline 9 & 156.9 & & $\mathrm{C}$ & & \\
\hline 10 & 103.1 & & $\mathrm{C}$ & & \\
\hline $1^{\prime}$ & 122.8 & & $\mathrm{C}$ & & \\
\hline $2^{\prime}$ & 114.6 & $7.76(1 \mathrm{H}, \mathrm{d}, J=1.38)$ & $\mathrm{CH}$ & & $\mathrm{C}-2,3^{\prime}, 6^{\prime}$ \\
\hline $3^{\prime}$ & 144.8 & & $\mathrm{C}$ & & \\
\hline $4{ }^{\prime}$ & 147.7 & & $\mathrm{C}$ & & \\
\hline $5{ }^{\prime}$ & 114.9 & $6.92(1 \mathrm{H}, \mathrm{d}, J=8.4)$ & $\mathrm{CH}$ & $\mathrm{H}-6^{\prime}$ & C-1', 3', 4', \\
\hline $6^{\prime}$ & 120.3 & $7.67(1 \mathrm{H}, \mathrm{dd}, J=8.4,1.7)$ & $\mathrm{CH}$ & $\mathrm{H}-5$, & $\mathrm{C}-2,2^{\prime}, 4^{\prime}$ \\
\hline
\end{tabular}

Table 2. Summary of 1D and 2D spectral data for Compound 2 (CD30D, $600 \mathrm{MHz}$ ).

\begin{tabular}{|l|l|l|l|l|l|}
\hline Position & $\boldsymbol{\delta}^{{ }^{3} \mathbf{C}}$ & $\boldsymbol{\delta}^{1} \mathbf{H}, \boldsymbol{J}(\mathbf{H z})$ & DEPT & COSY & HMBC \\
\hline 2 & 146.7 & & $\mathrm{C}$ & & \\
\hline 3 & 100.0 & & $\mathrm{C}$ & & \\
\hline 4 & 176.0 & & $\mathrm{C}$ & & \\
\hline 5 & 161.1 & & $\mathrm{C}$ & & \\
\hline 6 & 97.9 & $6.21(1 \mathrm{H}, \mathrm{d}, J=1.56)$ & $\mathrm{CH}$ & $\mathrm{H}-8$ & $\mathrm{C}-8,5,7,10$ \\
\hline 7 & 164.2 & & $\mathrm{C}$ & & \\
\hline 8 & 93.1 & $6.42(1 \mathrm{H}, \mathrm{d}, J=1.50)$ & $\mathrm{CH}$ & $\mathrm{H}-6$ & $\mathrm{C}-6,7,9,10$ \\
\hline 9 & 156.9 & & $\mathrm{C}$ & & \\
\hline 10 & 103.1 & & $\mathrm{C}$ & & \\
\hline $1^{\prime}$ & 122.8 & & $\mathrm{C}$ & & \\
\hline $2^{\prime}$ & 147.3 & & $\mathrm{C}$ & & $\mathrm{C}-1^{\prime}$ \\
\hline $3^{\prime}$ & 114.4 & $7.76(\mathrm{br}, 1 \mathrm{H})$ & $\mathrm{CH}$ & $\mathrm{H}-6^{\prime}$ & \\
\hline $4^{\prime}$ & 144.8 & & $\mathrm{C}$ & & \\
\hline $5^{\prime}$ & 114.6 & $7.67(1 \mathrm{H}, \mathrm{d}, J=8.1)$ & $\mathrm{CH}$ & $\mathrm{H}-6^{\prime}$ & $\mathrm{C}-3^{\prime}$ \\
\hline $6^{\prime}$ & 114.8 & $6.92(1 \mathrm{H}, \mathrm{d}, J=8.5)$ & $\mathrm{CH}$ & $\mathrm{H}-5^{\prime}$ & $\mathrm{C}-1^{\prime}, 2,4^{\prime} 6^{\prime}$. \\
\hline $1^{\prime \prime}$ & 35.1 & 2.21 & $\mathrm{CH}_{2}$ & $\mathrm{H}-2^{\prime \prime}$ & \\
\hline $2^{\prime \prime}$ & 31.6 & 1.62 & $\mathrm{CH}_{2}$ & & \\
\hline $3^{\prime \prime}$ & 28.9 & 1.36 & $\mathrm{CH}^{\prime}$ & $\mathrm{H}-2^{\prime \prime}, \mathrm{H}-4^{\prime \prime}$ & $\mathrm{C}-5^{\prime \prime}$ \\
\hline $4^{\prime \prime}$ & 25.5 & 2.05 & $\mathrm{CH}_{2}$ & $\mathrm{H}-3^{\prime \prime}$ & \\
\hline $5^{\prime \prime}$ & 29.3 & 1.34 & $\mathrm{CH}_{2}$ & & $\mathrm{C}-3^{\prime \prime}$ \\
\hline $6^{\prime \prime}$ & 13.0 & 0.89 & $\mathrm{CH}_{3}$ & & \\
\hline $1^{\prime \prime \prime}$ & 22.3 & 0.93 & $\mathrm{CH}_{3}$ & $\mathrm{H}-1^{\prime \prime \prime}$ & $\mathrm{C}-2^{\prime \prime}, 4^{\prime \prime}$ \\
\hline
\end{tabular}

\section{Study limitation}

Two compounds were isolated from the ethylacetate fraction of Tapinanthus globiferus, however, testing the efficacy of the isolated compounds on different ailments is recommended for possible drug development. 


\section{Conclusion}

Chromatographic studies of ethylacetate fraction of Tapinanthus globiferus afforded two flavonoids 2-(3', 4'-dihydroxyphenyl)-3, 5, 7- trihydroxy-4H-chromane-4one (quercetin) and 2-(2, 4-dihydroxyphenyl)-5, 7-dihydroxy-3-(3-methylhexyl)-4Hchromen-4-one. This is the first report of isolation of these compounds from Tapinanthus globiferus growing on Vitex doniana.

\section{Acknowledgment}

Our special gratitude to Mr. Dilip Jagjivan, School of Chemistry and Physics, University of Kwa-Zulu Natal, Durban, South Africa, for running the 1D and 2D-NMR spectroscopy.

\section{Conflict of interests}

The authors declare that they do not have any conflict of interests.

\section{References}

Abedo, J. A.; Jonah, O. A.; Abdullahi, R. S.; Mazadu, M. R.; Idris, H. Y.; Muhammed, H.; Shettima, F. T.; Ombugadu, S.; Daudu, M.; Garba, J.; Abdulmalik, U.; Kugu, B. A.; Usman, A. O. Evaluation of trypanosomal activity of Tapinanthus globiferus and Gongronema latifolium on Trypanosoma congolense. Bioscience Research, v. 10, p. 2-8, 2013.

Abubakar, K.; Adebisi, I. M.; Ugwah-Oguejiofor, J. C.; Idris, G. O.; Idris, B.; Mshelia, H. E. Phytochemical screening and anticonvulsant activity of the residual aqueous fraction of Tapinanthus globiferus growing on Ficus glums. Herbal Medicine: Open Access, v. 2, no. 2, 7, 2016. https://doi.org/10.21767/2472-0151.100013

Bassey, M. E. Phytochemical investigation of Tapinanthus globiferus from two hosts and the taxonomic implication. International Journal of Chemical Environmental and Pharmaceutical Research, v. 3, no. 2, p. 174-177, 2012.

Burkill, H. M. Useful plants of West Tropical Africa. 2. ed. Kew: Royal Botanic Gardens, 2000. v. 5.

Mabry, T. J.; Markham, K. R.; Thomas, M. B. The systematic identification of flavonoids. New York: Springer-Verlag, 1970.

Ogunbolude, Y.; Ibrahim, M.; Elekofehinti, O. O.; Adeniran, A.; Abolaji, A. O.; Rocha, J. B. T.; Kamdem, J. P. Effects of Tapinanthus globiferus and Zanthoxylum zanthoxyloides extracts on human leukocytes in vitro. Journal of Intercultural Ethnopharmacology, v. 3, no. 4, p. 167-172, 2014. https://doi.org/10.5455/jice.20140826110059

Polhill, R.; Wiens, D. Mistletoe of Africa. Kew: The Royal Botanic Garden, 1998.

Pratkit, C. Chemical constituent from the root bark and leaves of Artocarpus elasticus. Songkhla: Prince of Songkla University, 2010. (M.Sc. thesis).

Sani, Y. M.; Musa, A. M.; Abdullahi, S. M.; Nasir, T.; Abdullahi, M. I.; Atiku, I. Quercetin and $\beta$-sitosterol isolated from the methanol leaves extract of Cissus polyantha Glig and Brandt (Vitaceae). Nigerian Journal of Pharmaceutical Sciences, v. 14, no. 2, p. 46-50, 2015. 
Sher, H.; Alyemeni, M. N. Pharmaceutically important plants used in traditional system of Arab medicine for the treatment of livestock ailments in the Kingdom of Saudi Arabia. African Journal of Biotechnology, v. 10, p. 9153-9159, 2011. https://doi.org/10.5897/ AJB10.1570

Silva G. L.; Lee, I.; Douglas K. A. Special problems with extraction of plants. In: Cannell, J. P. R. (Ed.). Natural products isolation. New Jersey: Human Publishers, 1998. p. 251-293.

Waterberg, F.; Craven, P.; Marais, L. Common world flowers of the Okavango Delta. Namibia: Gamsberg Publishers, 1989. (Shellfield guide series II).

Yineger, H.; Yewhalaw, D. Traditional medicinal plant knowledge and use by local healers in Sekoru District, Jimma Zone, Southwestern Ethiopia. Journal of Ethnobiology and Ethnomedicine, v. 3:24, 2007. https://doi.org/10.1186/1746-4269-3-24 